\title{
Land and economic policies of Japan in the colonial Taiwan frontier: A case study on the Da-Nanao plain
}

\author{
Huang wenchuan \\ Department of Taiwan and Regional Studies, National Dong Hwa University, Taiwan
}

Email address:

sunnyhuang@mail.ndhu.edu.tw

\section{To cite this article:}

Huang wenchuan. Land and Economic Policies of Japan in the Colonial Taiwan Frontier: A Case Study on the Da-Nanao Plain. Humanities and Social Sciences. Vol. 2, No. 6, 2014, pp. 182-186. doi: 10.11648/j.hss.20140206.16

\begin{abstract}
After the first Sino- Japanese war in 1895, Japan finally realized possession of Taiwan. As Taiwan was Japan's first overseas colony, Japanese intentions were to turn the island into a "model colony." In order to more reasonably manage the land, the Japanese authority started to census the plain, forest and wilderness land. According to Japanese survey, about three-quarters of the land were in the hands of Japanese colonialists. Japanese colonial regime conducted its capitalism strategy at these public lands were mostly located in Taiwan frontier , including not only central mountains and its surrounding areas ,but also the Eastern Taiwan. This paper reviews the history of colonialism and further explores political and economic process of regional development on Taiwan frontier. It takes the case of the Da-Nanao plain and discusses how land policy influenced regional development and change during the Japanese colonial era. Apparently, even though such a wilderness frontier also follows the rule that the colony is designed to supply the colonist resources and materials needed.
\end{abstract}

Keywords: Land Policy, Taiwan Frontier, Colonial Economy, Region Development

\section{Introduction}

Taiwan came under the rule of the Chinese empire from 1684 to 1895 . In the Qing dynasty ,the governing policy of Taiwan was "spatial confinement" (Shi Tien-fu, 2001: 88). By applying this isolation policy, the different ethnics on the island contained each other. Finally, the outside area of the border, the so-called Taiwan frontier, still has been little populated and limited development. Taiwan frontier region(sherpherd,1995: 8) was known as the Han Chinese and Taiwan mountain abriginals contact zone. Not until the Botan (牡丹社) Incident in 1874, Shen Bao-tseng (沈葆楨)changed the original policy to an "appeasing aborigines and developing mountains" policy. Shen focused on encouraging immigrants to move into the border region but with limited effect. Eventually, the new policy was halted in 1883. Liu Ming-Chuan (Liu Ming-Chuan: 303-305 )restarted it again on but failed, too. The Qing dynasty's control of the border region finally came to an end in 1895, when the Japan regime occupied Taiwan .

While governing Taiwan, Japanese Minister Mizuno Zun Nai o $f$ the Interior Affairs Office has regarded Taiwanese aboriginal people as brutal, untamed killers of innocent. However, he also suggested that the mountains aboriginals occupied valuable for logging, planting and mining. Japanese emigration to Taiwan was relying on mountain management. The Japanese regime needed to win the allegiance of the masses. In order to tame the Taiwanese indigenous people, Japan had to use force, however a policy of appeasement and education policy was implemented at the same time (Ino Yoshinori, 1904:629).

This article mainly look at Da-Nanao plain located at the southern border of I-Lan county as a case-study. In the early stages of the Japanese regime period, Da-Nanao plain was still an uninhabited wilderness that became a new stronghold which attracted capitalist investment and immigrants. This article reviews the colonial-based economic strategy and explores what was the land policy for the Taiwan frontier region under the Japanese colonial regime.

\section{The Lands and Economic Resources of Colonial Taiwan}

In 1895 , the Japanese regime started to colonize Taiwan.Taiwan's economy during Japanese rule was for the most part, a standard colonial economy. Namely, the human and natural resources of Taiwan were used to aid the development of Japan. The primary economic policy of the 
Colonial Government was "industry for Japan, agriculture for Taiwan". From 1900 - 1920, Taiwan's economy was dominated by the sugar industry, while from 1920 - 1930, rice was the primary export. In order to make it easy to collect as much rice or sugar as possible and export it to Japan, Japan changed the land-ownership structure through cadastral survey and land registration.

As the chief civil administrator of the Taiwan Governor's Office, Goto Shinpei (後藤新平) arrived in Taiwan with the fourth governor, Kodama GentaroKodama(兒玉) together, in March 1898,until Kodama was replaced by the fifth governor in April, 1906.For a period of eight years, based on Goto's principle of "biological colonial management", various kinds of investigations and studies were undertaken. To begin with, the"Taiwan Land Register Regulations" and "Taiwan Land Investigation Regulations" were promulgated in 1898. ( Dr.Kiyoshi Ito :73).

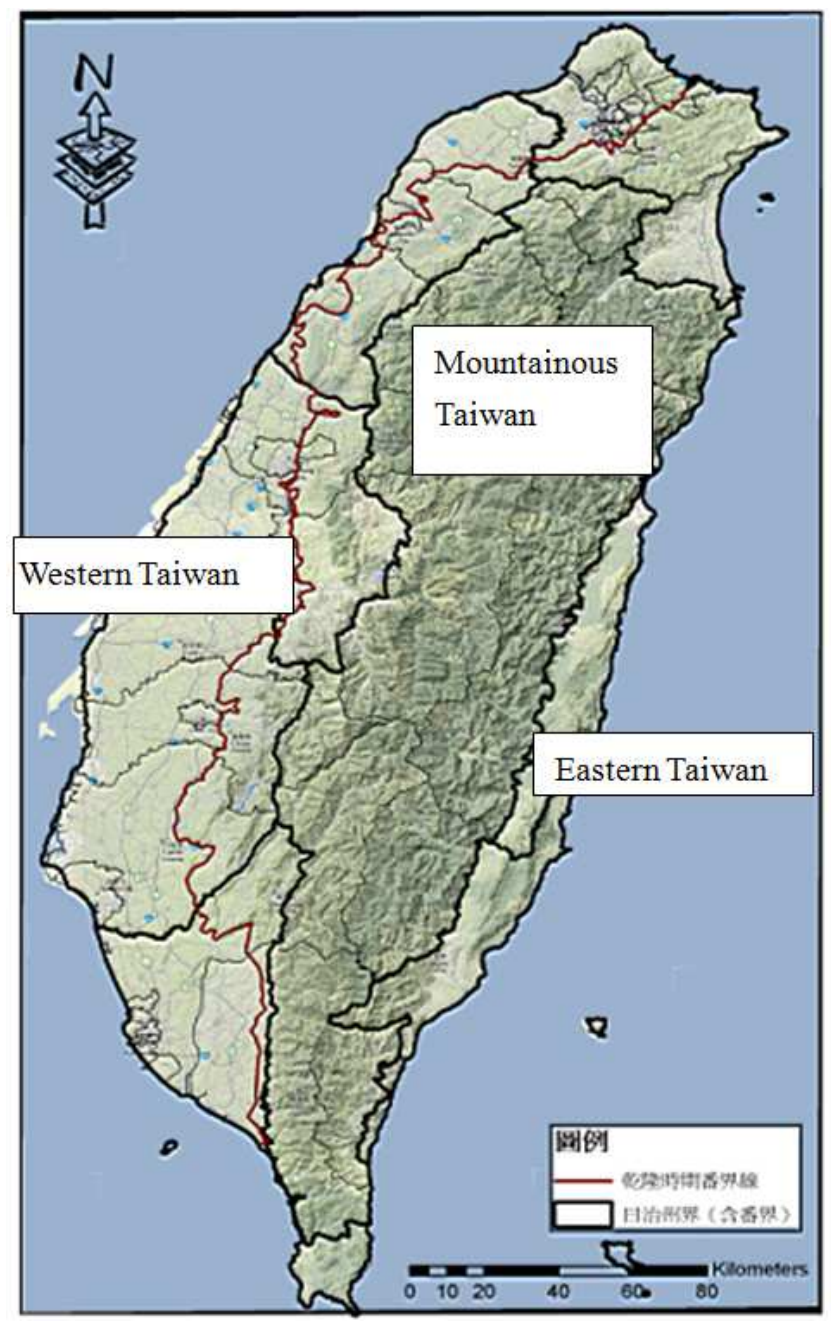

Fig 1. Taiwan aboriginal border line

Data: Ko Chi-ming, head of the Muscovy, Appendix: family law on Taiwan aborigine figure

Based on these investigations, it was discovered that the actually cultivated acreage was 317,000 jias $(1$ jia $=0.97$ hectare), other farmland was 305,600 jias, a total of 620,000 jias . Japan implemented the cadastral survey and land reform for the purpose of effectively designing and implementing agricultural and tax policies. Vast amounts of unclaimed or unregistered lands in the course of the cadastral survey and land registration, which the landed farmers hardly understood, were also confiscated by the Japanese Government General. Moreover, lands "without owner" were turned into public ownership, which were then distributed among retired officials or Japanese companies, helping Japanese capital to enter Taiwan. For specific purposes, the Taiwan Governor-General's Office implemented different methods and colonial policies for particular regions. It eventually divided Taiwan into three different parts (Fig 1: Shi Tien-fu ,2003 ).

The first part, named Western Taiwan, was located out of mountainous aboriginal boundery. This region had been a populated and fully developed area of traditional Chinese agriculture before the Japanese ruled Taiwan. The second part, named Eastern Taiwan, was between the eastern seashore and the central mountains. Taiwan Governor-General's Office set up agricultural colonization in this region and shifted it into a new immigrant's settlement. The third part, named Mountainous Taiwan, was located in the Central Mountain Range and along with the aboriginal border line. This region was full of towering forest resources and precious camphor could also be seen everywhere. Eventually, the Governor-General's Office took a step-by-step method to seize the abundant resources of the border region. These three regions were interacting with each other, but with obscure border lines. Especially, the development of the Western Taiwan and the Mountainous Taiwan of the border zone was a balance of aboriginal people (mountainous aboriginals) and Han Chinese (plain immigrants).

In fact, most of those unclaimed or unregistered lands were located in Mountainous Taiwan, where Han Chinese was afraid to settle down because of the aboriginal threat. Some of the lands seized by Government General in Taiwan were managed by Japanese corporations and others were distributed to Japanese settlers at bottom-low prices. (Woo:1991,pp.22-3) It was estimated that about $17.5 \%$ of the Taiwanese cultivated land was owned by the Japanese by 1938 (Taiwan Nien Chien, p.z R3). The land confiscated by the Japanese was mostly dry fields that were turned into sugar plantations.

\section{Military Force Blockade and New Territory on Taiwan Frontier}

We take the Da-Nanao plain in Ilan county as a case study. The Da-nanao plain is situated in the south of I-Lan county which was in the mountain region(Fig2), and under threat from the Tai-ya tribe(mountain aboriginal).Until the Japanese regime had tried to settle it, the Da-Nanaoa plain was still a wilderness (Taiwan Governor's Office official document 4672-6 ). The first obstacle of the Japanese needed to resolve was the issue of appeasing indigenous people and environmental control. 
In 1895, Taiwan was subsumed into Japanese territory, with the total collapse of the Qing dynasty frontier outposts, mountain aboriginals took the chance to intrude on Han people's properties. They not only destroyed camphor refinement and cultivation facilities, but also killed Han immigrants. The border region became chaotic .When Sakuma Samata (佐久間左馬太) was as the 5th Governor-General of Taiwan ( 1906 - 1915), and with the end of armed resistance by Taiwan's Han Chinese, the colonial authorities turned their attention to the suppression of the mountain aboriginals. During his tenure, Sakuma extended the "frontier guard line" which segregated the mountain aboriginals from those of the Han immigrants and flatland aborigines and shrank the life space of the mountain aborigines. With the frontier guard line expansion of 1903-1911 (Shi Tien-fu, 1996: 14-15 ), the mountain aboriginal, living on the Western and Southern border of Ilan, were fully contained by the frontier patrol-line, and the mountain area was kept in order.

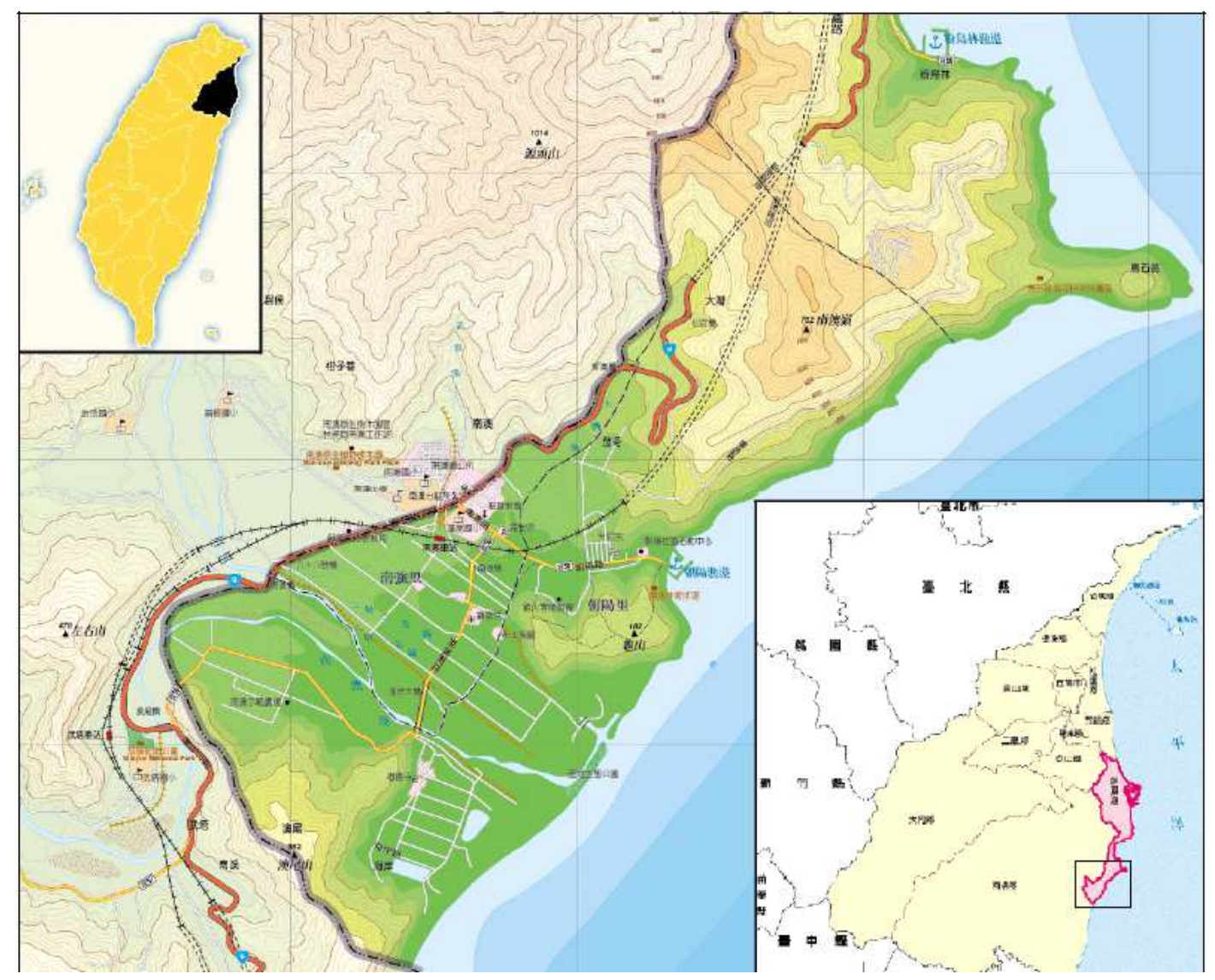

Fig 2. The location of Da-nanao plain

While the aboriginal threat was gradually decreasing, the border contact region of Han Chinese and mountain aboriginals was also stabling. In addition to contributing to the camphor business, the frontier guard system expansion also added new territories. All these lands become national new arable lands. How did the Taiwan Governor-General's Office manage these new lands? Who would have the permission to cultivate the wilderness? The question concerned the political strategy of Japan's colonial empire.

\section{New Immigrants and Lands Management}

In the case of the Da-Nanao plain, how did the Taiwan Governor-General's Office utilize these almost 1000 jias of new cultivable lands? As we knew, Japan was interested in the economic resources of its Taiwan colony. In 1908, after the
DaNaon expansion guard line was completely finished, the first attractive resource was the abundant camphor trees. The camphor trees was mainly distributed in the western and southern mountain areas of Ilan(The Taipei chou,1924 : 1092-1093), therefore Da-Nanao plain and Shan-shin area became important production locations for Taiwan's camphor company. The Shan-shin area based on its location close to the main towns of Ilan county, became the most important production location for Taiwan's camphor company. But after 1916, the Da-Nanao mountain area became the most productive camphor area, due to the mass hewing of camphor trees on Shan-shin mountain. This was a turning point for the colonial government and it had a new idea to manage the new territory. We can see the development process of Da-Nanao plain in three stages, the first stage is during 1908-1925, the second stage is during 1925-1937, and the third stage is during 1937-1945. 


\subsection{Camphor Business and Initial Residents: 1908-1925}

Based on the abundant camphor trees, the Da-nanao expansion guard line was completely finished in1908, all the treating aboriginals were contained by the guard line. From then on, the new territory of Da-Nanao plain became a new arable region even though there were still few residents and wilderness. Also ,because of camphor hewing, many Hakka people emigrated from the west of Taiwan to Da-Nanao plain(The Formosan newspaper: 1909.10.06).

Hakka, with their skilling with camphor ,became the initial residents,.In addition, some ,some Japanese mainly working for Taiwan's camphor company established by Japanese entrepreneurs also lived in Da-nanao plain.(The Formosan newspaper :1903.03.22) According to the record, there were only 301 Taiwanese and 72 Japanese living in this vast wilderness in 1925.(Table 1).But this great arable plain would be transformed into an agriculture area after the governor of Taipei state took project of immigrant settlements and cultivation of Da-Nanao plain.

Table 1. Population in the Da-nanao plain

\begin{tabular}{llll}
\hline time & Japanese & Taiwanese & Mountain aboriginal \\
\hline 1915 & 72 & 301 & \\
1920 & 59 & 366 & \\
1925 & 86 & 781 & \\
1930 & 39 & 1307 & \\
1935 & 39 & 2422 & 571 \\
1939 & 24 & 3566 & \\
\hline
\end{tabular}

Source: Taiwan Government office, The census of Taiwan:1915-1940

\subsection{The Project of Immigrant Settlements and Cultivation: 1925-1937}

Due to the outbreak of the European wars and the beet sugar cutbacks, the sugar price in the international market continued to rise. This also presented the Taiwan sugar industry with world market opportunities. In order to make it easy to collect as much sugar as possible and export it to Japan, Japan was able to significantly relieve pressure on its foreign exchanges. In Taiwan, the Government-General promoted the cultivation of sugarcane. The sugar cane planted zone of Taiwan began in southern Taiwan and slowly expanded to northern Taiwan. In 1916, Tainan Sugar Company moved from Tainan to the Ilan plain (Chan Chi-Wu, 1998: 119 ), the Ilan plain produced sugar manufacturing opportunities in the new development. Hence the Da-nanao plain, owning almost 1000 jias of arable but unclaimed or unregistered lands seized by Taiwan's Government General became an attractive reclamation area.

The Governor of Taipei state took over the project of immigrant settlements and cultivation of the Da-nanao plain in 1924. (The Formosan newspaper: 1924.01.01). Official drew up an immigration plan. They decided to build 3 settlements and cultivate 800 jias in serial years. In order to set up a model community of immigrants, the governor standardized all the immigrant's qualifications. In addition, the colonial government decided to build a traffic system (fig3) to attract immigrants to settle down. According to the record, 781 Taiwanese and 86 Japanese immigrated in the beginning, and then the population increased to 2422 in 1935 , almost 8 times more than last period. We also noticed that the most immigrants came from inner Taiwan but not from Japan. In fact, The Taiwan Governor's Office wanted Taiwanese to immigrate to cultivate the wilderness and to be tenants for the sugar manufacturing company.

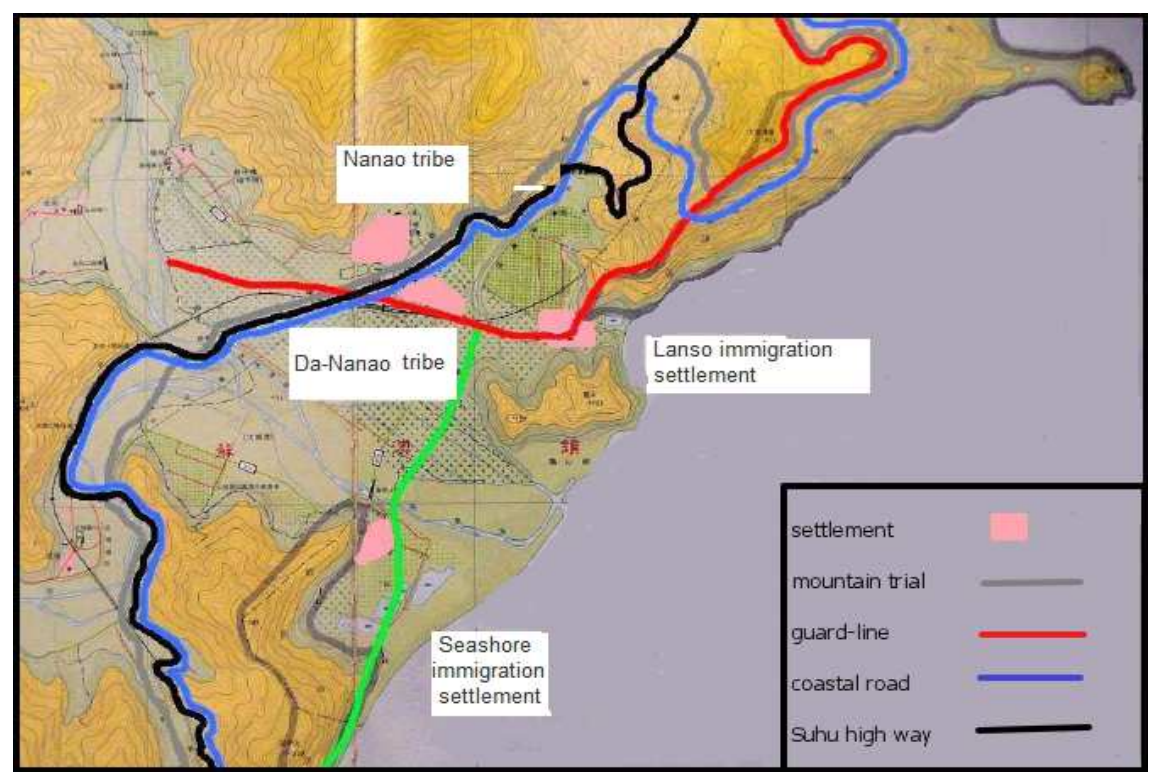

Fig 3. The traffic system and settlements

Source: Hong-Bin Chang, 2009, The migration Of Da-Nanao and Roads Building.p:88, Graduate of History, TamKang University. 


\subsection{Taiwan Colonization Company and Wartime Requirements 1937-1945}

On December 8, 1937, the Pacific War broke out, Japan was dashed into war chaos. Taiwan, as Japan's colony, was put under wartime structure. In order to cope with wartime requirements, Governor Kobayashi declared that his basic policies were to "industrialize" Taiwan, and to turn Taiwan into "a base" for the march towards Southeast Asia. (Dr. Kiyoshi, 110) Before entering into the Pacific War, Japan was ready for the "southward march". Symbolizing this intention was the "Taiwan Colonization Company", a national-policy corporation, which was set up by Imperial order in November 1936. "Taiwan Colonization Company" owned 15,000 jias of land, uncultivated fields, and forests owned by the Taiwanese Governor-General. Hence, "Taiwan Colonization Company" had all fields of the Da-nanao plain seized by Taiwan's Government General, too. The field of investment included: development, colonization, manufacturing, commerce, mining, transportation, entertainment, securities, etc.. (Taiwan Colonization Company,1936,1-8) In the beginning, the land policy of "Taiwan Colonization Company" in Da-nanao plain only for earned land rents,therefore, the DaNanao Development Company rented 264jias of land and The Dananao Immigration Society rented 246jias of land become great tenants. As the war expanded, it became necessary to increase the food supply, the Taiwan's Government General payed more funding to build irrigation systems in order to have better harvests. Even the Dananao plain also became the place of food production, finally.

\section{Conclusion}

In this article, we consider Japan as the first colonial empire to manage the colony of Taiwan. Based on the "Taiwan Land Register Regulations" and "Taiwan Land Investigation Regulations" promulgated in1898, most of no-owner lands located in the Taiwan frontier were discovered. In order to control the Mountain camphor resources, the Japanese regime began to carry out guard-line expansion to completely contain the aboriginal people. The expansion of guard-line, not only reduced threat from mountain aboriginals but also annexed more lands. The new territories of the Taiwan frontier turned into an investment business. But all the strategies of Japanese regime used in these new territories, also followed the rule that the colony is designed to supply the colonist the resources and materials needed.

\section{References}

[1] Chan Chi-Wu, 1998, The History and Social Change of Space, as the Case Study
[2] on the Ilan County, Taipei:House humic production Bureau,

[3] Huang wenchuan ,2003, Regional Development on Shan-shin Plain under the Japanese's Colonial Regime,Ph.D.diss,National Taiwan normal University,Taipei,Taiwan.

[4] Ino Yoshinori,1904, History of Aboriginal Policy in Taiwan, Taipei, Taiwan

[5] Ku Jen-jung, 1995, Betrayal and Nostalgia Luotung Forest Railway for Gays, The Ilan Documents Law (15): 99-109,Ilan, Tawain.

[6] The Ilan County Hall, 1911,The Fifth Book of Statistics of The Ilan County Hall,Ilan, Taiwan

[7] The Ilan County Hall, 1914; The Sixth Book of Statistics of The Ilan County Hall, Ilan, Taiwan

[8] The Ilan County Hall, 1916; TheSeventh Book of Statistics of The Ilan County Hall, Ilan, Taiwan

[9] Roy Denny ,2003. Taiwan: A Political History. Cornell University Press.

[10] Sherpherd,J.R.1995,Statecraft and Political Economy on the Taiwan Frantier (1600-1800 ),Stanford University Press.

[11] Shi Tien-fu, 1996, The Traditional Settlements in the Lanyang Plain - Theory and Basic Data (part 1).ILan ,Taiwan

[12] Shi Tien-fu, 2003, The Eastern Part of the Japanese Colonialism: Taiwan under the Second Discussion, Taiwan's Economic and Social history of the International Symposium: celebrate Wang Zai 3075 becoming law》 Taipei, Taiwan.

[13] Taiwan Governor's Office, the official document 4672-6,

[14] The Formosan newspaper: 1939.06.14; 1927.02.06

[15] The Taiwan Provincial Construction Department,1948, the Taiwan to law Conservancy. The Taiwan Provincial Construction Department.

[16] Dr.Kiyoshi Ito, (edited by Walter Chen.)"Taiwan-400 Years of History and Outlook"

[17] Taiwan Colonization Company ,1936, The law of Taiwan Colonization Company,Taipei Taiwan Colonization Company.

[18] Hong-Bin Chang, 2009, The migration Of Da-Nanao and RoadsBuilding,Graduate of History, TamKang University.

[19] Davidson, James W. The Island of Formosa: Past and Present. Macmillan and Company and Kelly and Walsh Ltd., 1903. Reprinted by SMC Publishing 1992.

[20] Hsu, Matsu. Culture Self, and Adaption: the Psychological Anthropology of Two Malayo-Polynesian Groups in Taiwan. The Institute of Ethnology, Academia Sinica, [Taiwan], 1991.

[21] Ka, Chih-Ming. Japanese Colonialism in Taiwan: Land Tenure, Development, and Dependency 1895-1945. Westview Press, 1995, Reprinted by SMC Publishing Inc., 1996 